\title{
FINANCING INFRASTRUCTURE IN THE POLISH TSL SECTOR FROM EU FUNDS
}

\author{
GRAŻYNA ROSA, ${ }^{1}$ TOMASZ SONDE ${ }^{2}$ \\ ${ }^{1}$ University of Szczecin, POLAND \\ e-mail: grazyna.rosa@wzieu.pl \\ ${ }^{2}$ WSB Universities, POLAND \\ e-mail: tomasz.sondej@wp.pl
}

RECEIVED
ACCEPTED
JEL
CLASSIFICATION

KEYWORDS

ABSTRACT

\begin{abstract}
4 December 2017
5 January 2018

F36, L91, L92

transport, TSL sector, infrastructure financing, EU funds

The article presents the stages and principles of financing the TSL sector, the description of national and regional programmes of financing the TSL sector infrastructure from European Union funds, special funds for new programmes in 2014-2020, and areas for financing projects in the TSL sector. The aim of these considerations is to analyse the financing of the TSL sector infrastructure in Poland from EU funds, while taking into account changes implemented in the next three financing prospects, as well as indicate development directions of this sector. In order to achieve this goal, the desk research method was applied in relation to the available literature and Internet sources. The article is of review character.
\end{abstract}

\section{Introduction}

Due to the non-uniformity of transport conditions in the Member States (e.g. excess and diversity of regulations, different conditions of infrastructure, different standard of services, diversity of information systems), the European Union attempts to coordinate activities supporting transport development, in particular intermodal transport, mainly in the form of financial support, which generally concerns the following areas (Rosa, 2017, p. 688): 
support of intermodality in the realized TEN-T network projects, development and functionality of logistics centres, harmonization of standards, integration of freight transport corridors and support of research projects in the field of intermodal transport. Public resources of individual countries are insufficient to the meet the financial needs related to transport investments.

Financing infrastructure in the transport-shipping-logistics (TSL) sector is part of the implementation of transport policy objectives. The infrastructure can be financed from (Liberadzki, Mindur, 2007, p. 467) public capital (central and local budget), private capital, and capital from support measures coming from EU funds. An important factor determining the efficient functioning of enterprises in the TSL sector are applied technologies. In literature on the subject and colloquial language, terms related to new technologies, such as combined, multimodal and intermodal transport, are often interchangeably used. These concepts were precisely defined in the "Terminology of Combined Transport" glossary published by the European Conference of Ministers of Transport (CEMT), (Mindur, Krzyżaniak, 2011, p. 11). Multimodal transport is understood as the transportation of goods by two or more modes of transport, where the goods may switch loading units. In intermodal transport, goods are moved in one and the same loading unit, which successively uses two or more modes of transport. Combined transport is classified as intermodal transport, where the major part of the loading unit journey is by rail, inland waterways or sea between terminals and any initial and/or final legs carried out by road are as short as possible (Mindur, 2014, p. 329 ). Rail and road transport should complement each other, assuming that goods are transported over long distances by trains, and "last-mile services" are provided primarily using lorries. Furthermore, the use of intermodal units, such as containers and swap bodies, should be promoted (Zwiększenie roli..., 2017, p. 3). There are many arguments supporting the development of intermodal transport, with the main ones including: changing the structure of freight transport, increasing the transport of goods, caring for the natural environment, reducing the external costs of transport.

The aim of the presented considerations is to analyse the financing of infrastructure in the Polish TSL sector from EU funds and to indicate the development directions of this sector. These considerations included indication of the stages and principles of financing the TSL sector, description of national and regional programmes of financing the TSL sector infrastructure from European Union funds, special funds for new programmes in 2014-2020, and identification of areas for financing projects in TSL sector.

In order to achieve the goal, the desk research method was applied in relation to the available literature and Internet sources.

\section{Stages and principles of financing the TSL sector from EU funds}

Financing the infrastructure development in the TSL sector from EU funds in Poland can be divided into three stages (Rosa, 2017, p. 701):

1. In the years 2004-2006, financing was carried out in accordance with the Transport Sectoral Operational Programme - Maritime Economy (SPOT) within a specified area of activity, namely the development of intermodal systems. The creation and development of such systems was possible thanks to the creation of logistic centres that also acted as intermodal terminals equipped with transshipment stations. As part of this programme, special emphasis was put on logistics centres and container terminals located on railway lines, which enabled the change of transport modes on the east-west and north-south directions. This task focused on financially supporting projects related to these activities from the European Regional 
Development Fund. The support amounted to EUR 21 million. National resources in this area amounted to EUR 8.9 million.

2. Under the financial perspective for the years 2007-2013, EU funds for financing transport were allocated in Poland in accordance with the Operational Programme Infrastructure and Environment (POliŚ). As Poland did not use the funds allocated to SPOT for the development of intermodal systems, the task was not mentioned in the new financial perspective. One of the objectives included in this programme for the priority axis, i.e., environmentally friendly transport, was the increase of intermodal transport share in the general cargo transport.

3. Under the new financial perspective for the years 2014-2020, EU funds for transport financing are being allocated in Poland in accordance with the Operational Programme Infrastructure and Environment (POliŚ) - Priority axis III: Development of the TEN-T road network and multimodal transport.

The perspective for 2014-2020 is implemented in Poland through 6 national operational programmes managed by the Ministry of Development, and 16 regional programmes managed by Marshal Offices (Table 1).

Table 1. EU funds in national programmes in the years $2014-2020$

\begin{tabular}{clc}
\hline No. & \multicolumn{1}{c}{ Programme name } & $\begin{array}{c}\text { Financial resources from EU funds } \\
\text { billion EUR }\end{array}$ \\
\hline 1. & Infrastructure and Environment Programme & 27.4 \\
2. & Smart Growth Programme & 8.6 \\
3. & Knowledge, Education, Growth Programme & 4.7 \\
4. & Digital Poland Programme & 2.2 \\
5. & Eastern Poland Programme & 2.0 \\
6. & Technical Assistance Programme & 0.7 \\
\hline
\end{tabular}

Source: Co można... (2018).

The highest amount of funds were allocated for the Infrastructure and Environment Programme, whose priorities are low-emission economy, environmental protection, development of technical infrastructure of the country, and energy security.

At the national level, 19 smart specializations have been defined within 5 thematic areas. The closest national smart specialization to the sector of logistics, shipping, and transport is specialization No. 9, i.e., environmentally friendly transport solutions, and possibly No. 14 - Sensors (including biosensors) and smart sensor networks.

In the field of transport, the emphasis is put on clean communication, especially the development of rail transport. In justified cases, it is possible to finance other forms of low-emission transport, such as trolleybuses or electric buses. Moreover, investments in infrastructure (e.g. construction, reconstruction, development of rail and energy networks, transfer centres, and elements of road and street infrastructure serving public transport and passengers) and rolling stock can be implemented. Particular attention is given to combination of both types of these projects. Furthermore, complementary infrastructure projects, such as intelligent transport systems, integration of existing transport means and adaptation of communication to the needs of people with disabilities, will also be funded (Fundusze unijne..., 2018) 


\section{National programmes for financing infrrastructure in the TSL sector from Eurpopean Union funds}

The largest programme financed from European Funds not only in Poland, but also in the whole European Union, is the Infrastructure and Environment Programme 2014-2020. Thanks to the balance kept between investment in infrastructure and support directed to selected areas of the economy, the programme can effectively implement the Europe 2020 strategy, whose main aim is to support a resource-efficient and environmentally friendly economy as well as social and territorial cohesion (Co można..., 2018). The areas of support and types of projects that can be implemented under the Infrastructure and Environment Programme 2014-2020, and which relate to, at least partially, transport issues, include (Co można..., 2018):

1. Development of the TEN-T road network and multimodal transport, including: development of road infrastructure in the TEN-T network, improvement of road safety, improvement of air traffic safety, intermodal, sea and inland transport.

2. Road infrastructure for cities, including improving the accessibility of cities and the capacity of road infrastructure (development of road infrastructure in cities and outgoing routes from cities, construction of bypasses).

3. Development of rail transport in Poland, including the development of railways in TEN-T, outside the network and city railways.

4. Development of low-emission public transport in cities, including infrastructure and rolling stock for public transport in cities and their functional areas.

The Infrastructure and Environment Programme is financed from three sources (Sposób finansowania..., 2018):

- The European Regional Development Fund that allocates EUR 4,905.9 million for the programme,

- The Cohesion Fund, allocating EUR 22,507.9 million,

- National funds - public and private, which amount to EUR 4,853.2 million minimum.

Under the financial perspective 2014-2020, support for this type of investment is continued primarily under the POliS programme, Priority axis III: Development of the TEN-T road network and multimodal transport, number and name of the priority/action/sub-measure: Measure 3.2. Development of maritime transport, inland waterways and multimodal connections (Dotacje unijne..., 2018). Under this measure, the types of projects eligible for financing in intermodal transport can be distinguished (Rozwój transportu..., 2018): construction and reconstruction of intermodal terminal infrastructure, including terminals located in logistic centres and seaports, together with a dedicated railway (including sidings)/road infrastructure, which is necessary for their inclusion into the railway lines/road network, as well as the construction/ reconstruction of utilities necessary for the terminal's operation:

1. Purchase and/or modernization of devices necessary for the operation of intermodal terminals, in particular lifting devices and other devices for reloading of shunting locomotives.

2. Purchase and/or modernization of telematics and satellite systems (devices and software) related to intermodal transport, as well as expenses for their implementation.

3. Purchase and/or modernization of rolling stock, including switcher locomotives, and specialized carriages for intermodal transport (platform).

The institution that announces the competition is the Centre for EU Transport Projects (www.cupt.gov.pl, 2018). As part of the support for investments aimed at the development of intermodal transport, the priority Axis will 
comprise projects concerning the modernization and extension of existing terminals, as well as the increase in their number, including intermodal terminals located in logistic centres and seaports.

The following project types will be implemented under the Cohesion Fund:1

- construction or extension of infrastructure that is part of railway or maritime container terminals,

- construction or extension of infrastructure that is part of logistic centre located in seaport or on a railway line,

- purchase of equipment used to manage the terminal/logistics centre.

Thanks to the construction of public container terminals and logistic centres on railway lines and in seaports, as well as the introduction of modern management techniques in terminals and logistics centres, there is a growing interest in intermodal transport presented as an alternative to the previously used forms of goods transport. Since the state is interested in the dynamic development of the intermodal transport system, it should be supported from public funds. This support can (potentially) take several forms (Engelhardt, 2015, p. 29):

- subsidizing charges levied for access to intermodal train infrastructure,

- subsidizing purchases of intermodal rolling stock,

- subsidizing investment expenditures in the scope of construction of railway intermodal (logistic) terminals,

- subsidizing the activities of intermodal transport operators or cargo managers, who send shipments using combined transport from the National Fund for Environmental Protection and Water Management.

Subsidizing telematics and satellite systems that provide users with real-time information on the current location of the transported cargo, and thus optimize and control transport processes, will contribute to shortening the delivery time and reducing the threat to the condition of transported loads (Centra logistyczne..., 2018).

\section{Regional programmes for financing infrastructure in the TSL sector from European Union funds}

In addition to national programmes, EU funds are also allocated among 16 regional programmes, whose goal is to support the development of all regions. In this case, the funds are managed not by central authorities, but local government institutions, i.e. voivodeship boards. The differentiation of EU funds allocated to regional programmes in 2014-2020 is presented in Table 2.

Table 2. EU funds in regional programmes in 2014-2020

\begin{tabular}{clc}
\hline No. & \multicolumn{1}{c}{$\begin{array}{c}\text { Regional programmes } \\
\text { per voivodship boards }\end{array}$} & $\begin{array}{c}\text { EU funds in regional programmes } \\
\text { in 2014-2020 (billion euros) }\end{array}$ \\
\hline 1 & \multicolumn{1}{c}{2} & 3 \\
\hline 1. & Dolnoślaskie & 2.25 \\
2. & Kujawsko-pomorskie & 1.90 \\
3. & Lubelskie & 2.23 \\
4. & Lubuskie & 0.90 \\
5. & Lódzkie & 2.25 \\
6. & Małopolskie & 2.87 \\
7. & Mazowieckie & 2.08 \\
8. & Opolskie & 0.90 \\
9. & Podkarpackie & 2.10 \\
\hline
\end{tabular}

${ }^{1}$ http://www.cupt.gov.pl (2018). 


\begin{tabular}{clc}
\hline 1 & \multicolumn{1}{c}{2} & 3 \\
\hline 10. & Podlaskie & 1.21 \\
11. & Pomorskie & 1.86 \\
12. & Śląskie & 3.47 \\
13. & Świętokrzyskie & 1.36 \\
14. & Warmińsko-mazurskie & 1.72 \\
15. & Wielkopolskie & 2.45 \\
16. & Zachodniopomorskie & 1.60 \\
\hline
\end{tabular}

Source: Co można... (2018).

On the other hand, each voivodeship chose its own regional specializations focusing on issues considered a priority. In many regions, these issues are directly related to logistics, transport and forwarding. For example, "Specialized logistics processes" was selected in Wielkopolskie voivodeship, whereas Pomorskie voivodeship chose "Logistics, business services" (Kaim-Mierzwicka, 2018) while Zachodniopomorskie voivodeship "Maritime activity and logistics" (Regionalny Program..., 2018).

Regional Programmes are focused on comprehensive support for voivodeship development. Each programme has its particular characteristics resulting from regional conditions and strategies, the basis for which, however, were national and EU thematic objectives (Regionalne programy..., 2018). Regional Programmes operate in parallel to national programmes - in both cases, the same objectives were taken into account, but with different approach. In accordance with the strategic plans adopted in Poland for the purposes of preparing programmes for 2014-2020, in the field of transport, mainly the regional and local transport infrastructure, i.e., public transport in cities, should be supported from the European Regional Development Fund (Regionalne programy..., 2018).

\section{Special funds for new programmes in the years 2014-2020}

In addition to existing funds, the European Union has allocated special funds for new programmes for 2014-2020 that are aimed at providing additional support in various areas (Programy ramowe..., 2018). In case of transport, it will be the programme named "The Connecting Europe Facility" (Instrument..., 2018), which will be the most important instrument financing strategic investments in infrastructure in the field of road construction, railway lines, energy networks, as well as the development of information and communication technologies (EUR 33 billion).

In Poland, as well as in other countries, the forthcoming years will be a period of increased investment in transport infrastructure. It is therefore possible to further increase these levels by supporting PPP solutions and other incentives for private capital. Investment projects in transport tend to be more complex than investments in other industries, as they often involve more stakeholders and are dependent on more factors. In the period up to 2020 , a special focus on the selection of reliable contractors and supervision over the implemented investments is recommended, so that ambitious plans can be implemented in accordance with the aims.

Potential sources of support for projects from the TSL sector can be found in the following EU programmes (cf. Kaim-Mierzwicka, 2015):

\section{Smart Growth Operational Programme:}

1. Performance of R\&D works/construction and extension of RDC:

- projects aimed at developing new products or services,

- projects for national smart specializations, 
- projects with eligible costs exceeding PLN 2 million.

2. Implementation of innovative technologies:

- projects involving the implementation of an innovative solution in the company,

- projects for national smart specializations,

- projects with a higher value of eligible costs.

\section{Infrastructure and Environment Operational Programme:}

1. Environmentally friendly projects:

- projects concerning raw material and energy savings implemented by large enterprises,

- projects concerning production of energy from renewable energy sources (RES) - installations with more power.

\section{Regional Operational Programmes:}

1. Performance of R\&D works/ construction and extension of RDC:

- projects aimed at developing new products or services,

- projects for regional smart specializations,

- projects with eligible costs not exceeding PLN 2 million.

2. Implementation of innovative technologies:

- projects involving the implementation of an innovative solution in the company,

- projects for national smart specializations,

- projects with a lower value of eligible costs.

3. Information and Communication Technologies:

- projects involving the purchase and implementation of new IT solutions to launch new e-services,

- projects implemented by SMEs.

4. Environmentally friendly projects:

- projects concerning raw material and energy savings implemented by SMEs,

- projects concerning production of energy from renewable energy sources (RES) - installations with less power.

\section{Funding areas for projects from the TSL sector}

According to Katarzyna Kaim-Mierzwicka (2018), areas that could be potentially financed from the TSL sector projects include:

a) Conducting research-development works

One of the main areas of support for enterprises under the new EU perspective is co-financing of research and development activities. The funds will be granted at the national level, under Smart Growth Operational Programme (SG OP), and at the regional level from regional operational programmes (ROP). They should address issues covered by national or regional smart specializations, depending on the programme under which the application is submitted. In addition to support for research and development, it will be possible to apply for funds for the creation or development of research and development centres (RDC). Under this type of projects, it will be possible to purchase the equipment necessary to conduct the tests. 
b) Implementation of innovative technologies in the operations of enterprises

As part of projects belonging to this category, entrepreneurs will be able to obtain co-financing for investment costs related to the development of their enterprise. In general, the aim of bearing investment costs is to implement an innovative solution at the company, e.g. a new way of labelling and identifying goods in the industry that allow significant time and cost savings (Kaim-Mierzwicka, 2015)

c) Information and communication technologies (ICT) related projects

As part of the ROP, small and medium-sized enterprises will be able to obtain co-financing for the implementation of projects related to the purchase and implementation of new IT solutions. However, projects cannot regard only the purchase of equipment. They should constitute comprehensive projects, which may result in, e.g. the launch of new e-services, a change in the way of communicating with business partners (B2B) and clients (B2C) or the automation of business processes.

d) Projects regarding pro-environmental solutions

Different types of projects, for which it is possible to indicate decreased demand for energy, water or other raw materials, will be supported under the so-called pro-environmental projects. This category also includes undertakings aiming at the production of energy from renewable sources (RES) - sun, wind, water, biomass, biogas, etc. The planned projects can be referred to specific modes of transport.

In the area of road transport, the largest part of the funds will be allocated for investments in national roads and expressways. In the current EU financial perspective, the government wants to allocate PLN 140 billion for the construction of modern roads. These financial resources will come from national and EU funds, with subsidies obtainable from the EU amounting to PLN 48 billion. By 2023, $1800 \mathrm{~km}$ of new roads, mainly motorways and expressways, are planned to be built. Thanks to the support of the European Union, the road network of the highest standard in Poland increased almost three times between 2004 and 2013 (National Road Construction Programme 2011-2015, 2018, National Road Construction Programme for 2014-2023, 2018). Road transport remains the dominant means of transport in Poland. In 2014, around $80 \%$ of transport was carried out by cars on the TSL market, and in 2020 this number will increase to $82 \%$. Therefore, an important issue is further increase in road capacity.

The assessment of EU experts regarding the functioning of Polish rail transport is actually negative. Despite EU investments, the functioning of rail transport is still unsatisfactory due to traffic restrictions and degraded infrastructure (currently about half of the $19,000 \mathrm{~km}$ of railway lines are in good technical condition (Wieloletni..., 2018). The other factor that lowers competitiveness of rail transport is high fees for access to infrastructure. The low popularity of rail transport results in increased negative environmental effects such as greenhouse gas emissions, air and noise pollution (Grunert, 2016, pp. 1-2). In the years 2014-2020, approximately PLN 22 billion is planned to be spent on investments in railway infrastructure from EU funds. In total, by 2023 , Polish government intends to allocate PLN 31 billion to investments in rail transport (according to the "The National Railway Programme 2023"). PKP PLK (Polish Railways) assumes further modernization and revitalization of the existing network of railway lines, including high-speed rail on the most important connections. The speed of trains planned by PKP PLK is $160 \mathrm{~km} \mathrm{~h}$ for passenger trains and $120 \mathrm{~km} / \mathrm{h}$ for freight trains (Centrum logistyczne..., 2018).

Moreover, it is planned that EU investments in 2014-2020 in maritime transport will amount PLN 6.5 billion, which is more than a 2.5 -fold increase when compared to the 2007-2013 perspective. The Container Terminal 
in Gdańsk will increase its capacity from 1.5 million TEU to 4.5 million TEU by 2020. Over PLN 1.3 billion will be allocated for investments in ports in Świnoujście and Szczecin (Centrum logistyczne..., 2018).

The European Union spent approximately EUR 615.7 million in 2007-2013 to support aviation infrastructure in Poland. Further expenditure on aviation infrastructure in Poland will be significantly reduced in the coming years. It is assumed that the Polish air transport sector will grow at an average annual rate of 3.7\% in 2014-2019. The European Commission has limited the financing of airports by 2020 due to the well-developed network of airports in Poland (Centrum Logistyczne..., 2018).

\section{Conclusions}

The lack of a coherent concept of infrastructure development in the TSL sector has led to the formation of the national logistic system different from those in Western European countries. Analysing the experiences of these Western European countries, it seems that the most appropriate way is to finance TSL infrastructure and create logistic centres based on the public-private partnership that involves funds from the private, local government and government administration sectors (Jacyna, 2013, pp. 100-103).

In the case of large investments, which require high amount of financial resources, additional co-financing from European Union subsidies, called the hybrid model, may be required (Mindur, 2007, p. 311). However, despite the considerable support from the European Union, sometimes reaching $85 \%$ of the value of investments, there is a need to look for new sources of financing for infrastructure projects. Private capital can be an important source of supporting transport investments. Considering the fact that the infrastructure is a public good, only in exceptional cases can it be financed by private capital. In Poland, the justification for such solution is the high budget deficit, which means that entities responsible for infrastructure financing, the state, and local governments, are not able to fully fulfil their task.

\section{Referencess}

Centra logistyczne (2018). Retrieved from: http://www.strategor.pl/centra-logistyczne.

Centrum logistyczne Europy przesuwa się z Niemiec do Polski (2018). Retrieved from: http://www.pwc.pl/pl/media/2015/2015-11-17centrum-logistyczne-europy-przesuwa-sie-z-niemiec-do-polski.html (17.02.2018).

Centrum Unijnych Projektów Transportowych (2018). Retrieved from: http://www.cupt.gov.pl/.

Co można zrealizować (2018). Retrieved from: https://www.pois.gov.pl/strony/o-programie/zasady/co-mozna-zrealizowac.

Dotacje unijne: Trwają konsultacje Programu Infrastruktura i Środowisko 2014-2020 (2018). Retrieved from: http://www.dotacja-unijna. com/wiadomosci,akt-2,wiad-180.html,Dotacje+unijne+Trwaja+konsultacje+Programu+Infrastruktura+i+Srodowisko+2014-2020.

Engelhardt, J. (2015). Polityka państwa w zakresie transportu intermodalnego w Polsce. In: W. Rydzkowski (ed.), Przewozy intermodalne. Biblioteka Logistyka. Poznań: ILiM.

Fundusze unijne 2014-2020 (2018). Retrieved from: http://www.transport-publiczny.pl/watki/fundusze-unijne-20142020.html.

Grunert, E. (2016). Pilna potrzeba poprawy transportu kolejowego. Polska Gazeta Transportowa, 10, 9 March.

Instrument „Łącząc Europę” (2018). Retrieved from: https://www.funduszeeuropejskie.gov.pl/strony/o-funduszach/zasady-dzialaniafunduszy/program-laczac-europe.

Jacyna, M. (eds.) (2013). System logistyczny Polski. Warszawa: Oficyna Wydawnicza Politechniki Warszawskiej.

Kaim-Mierzwicka, K. (2018). TSL też wpisuje się w trendy nowej perspektywy. Retrieved from: http://taxand.pl/crido-taxand-i-bankbph-zapraszaja-na-cykl-regionalnych-spotkan-dot-funduszy-ue-2014-2020-dla-firm/tsl-tez-wpisuje-sie-w-trendy-nowejperspektywy.

Liberadzki, B., Mindur, L. (eds.) (2007). Uwarunkowania rozwoju systemu transportowego Polski. Radom: Wydawnictwo ITE-PIB. 
Mindur, L. (eds.) (2014). Technologie transportowe XXI wieku. Warszawa-Radom: Wydawnictwo Naukowe Instytutu Technologii Eksploatacji-Państwowy Instytut Badawczy.

Mindur, L. (2014). Transport kombinowany/intermodalny. In: L. Mindur (ed.), Technologie transportowe. Warszawa-Radom: Wydawnictwo Naukowe Instytutu Technologii Eksploatacji-Państwowy Instytut Badawczy.

Mindur, L. (ed.) (2007). Europa - Azja, Gospodarka. Transport. Poznań: Wydawnictwo ILiM.

Mindur, L., Krzyżaniak, S. (eds.) (2011). Tworzenie warunków funkcjonowania i rozwoju intermodalnej sieci logistycznej w Polsce. Aspekty metodyczne. Poznań: Instytut Logistyki i Magazynowania.

Mindur, M. (ed.) (2017). Logistyka. Nauka-Badania-Rozwój. Warszawa-Radom: Wydawnictwo ITE-PIB.

Program budowy dróg krajowych 2011-2015. Uchwała Rady Ministrów nr 10/2011 z 25 stycznia 2011 r. w sprawie ustanowienia programu wieloletniego pod nazwa „Program Budowy Dróg Krajowych na lata 2011-2015” (2018). Retrieved from: http://mib.gov. pl/media/3733/Uchwala_RM_nr_10_2011_z_25_stycznia_2011.pdf.

Program budowy dróg krajowych na lata 2014-2023, Uchwała nr 105/2017 Rady Ministrów z 12 lipca 2017 r. zmieniająca uchwałe w sprawie ustanowienia programu wieloletniego pod nazwą „Program Budowy Dróg Krajowych na lata 2014-2023 (z perspektywą do 2025 r.)" (2018). Retrieved from: https://www.gddkia.gov.pl/userfiles/articles/ k/konsultacje-spoleczne-prognozy-0_18875/ TOM\%20D\%20-\%20Projekt\%20PBDK_Konsultacje.pdf.

Programy ramowe Unii Europejskiej (2018). Retrieved from: https://www.pois.gov.pl/strony/o-programie/zasady/co-mozna-zrealizowac.

Regionalne programy operacyjne (2018). Retrieved from: http://www.dotacja-unijna.com/unijne,link-86.html,Regionalne+Programy+0 peracyjne+RPO.

Regionalny Program Operacyjny Województwa Zachodniopomorskiego 2014-2020. Retrieved from: http://www.rpo.wzp.pl/sites/ default/files/dokument_rpo_15.pdf.

Rosa, G. (2017). Uwarunkowania rozwoju logistyki na świecie i w Polsce - płaszczyzna finansowa. In: M. Mindur (ed.), Logistyka. Nauka-Badania-Rozwój. Warszawa-Radom: Wydawnictwo ITE-PIB.

Rozwój transportu intermodalnego (2018). Retrieved from: http://www.dotacja-unijna.com/unijne,link-24,podlink-31,p.- 79. Html.

Sposób finansowania programu (2018). Retrieved from: http://www.pois.gov.pl/strony/o-programie/zasady/finansowanie.

Wieloletni program inwestycii kolejowych do roku 2015. Uchwała nr 162/2015 Rady Ministrów z 15.09.2015 w sprawie ustanowienia Krajowego Programu Kolejowego do 2023 r. ( 2018). Retrieved from: https://mib.bip.gov.pl/fobjects/download/90191.

Cite this article aS: Rosa, G., Sondej, T. (2018). Financing infrastructure in the Polish TSL sector from EU funds. European Journal of Service Management, 1 (25), 243-252. DOI: 10.18276/ejsm.2018.25-30. 